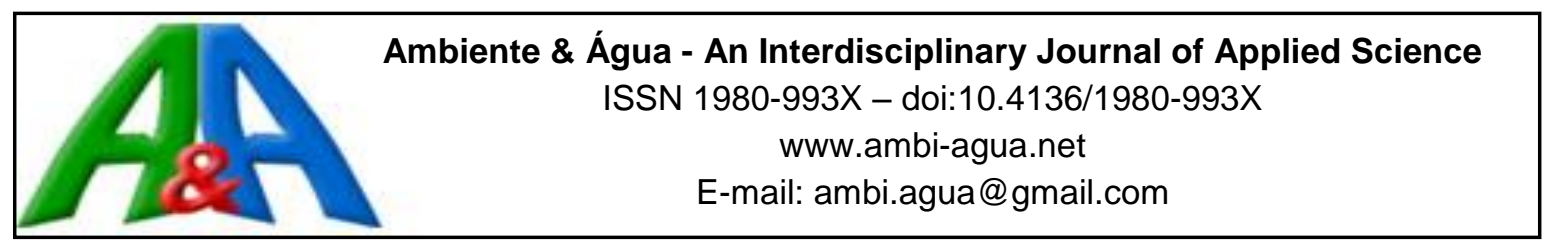

\title{
Modeling and hydraulic performance evaluation of a dripper device coupled to a branched water distribution network
}

\author{
ARTICLES doi:10.4136/ambi-agua.2340
}

Received: 03 Oct. 2018; Accepted: 24 Mar. 2019

\author{
Renato Braga Zanca1 ${ }^{1}$; Fernando das Graças Braga da Silva ${ }^{1 * i D}$; \\ Daniele Ornaghi Sant Anna ${ }^{1 D}$; Alex Takeo Yasumura Lima Silva1 ${ }^{1}$; \\ Hélcio Francisco Villa Nova ${ }^{2}$; Ivan Felipe dos Santos ${ }^{1}$ iD; \\ José Antônio Tosta dos Reis ${ }^{3}$ (D)
}

\author{
${ }^{1}$ Universidade Federal de Itajubá (UNIFEI), Itajubá, MG, Brasil \\ Instituto de Recursos Naturais (IRN). E-mail: renatozanca1@yahoo.com.br, ffbraga.silva@gmail.com, \\ ornaghi@unifei.edu.br, alex.takeo@uol.com.br, ivanfelipedeice@ hotmail.com \\ ${ }^{2}$ Universidade Federal de Itajubá (UNIFEI), Itajubá, MG, Brasil \\ Instituto de Engenharia Mecânica (IEM). E-mail: helcio.villanova@unifei.edu.br \\ ${ }^{3}$ Universidade Federal do Espírito Santo (UFES), Vitória, ES, Brasil \\ Departamento de Engenharia Ambiental.E-mail: jatreis@gmail.com \\ *Corresponding author
}

\begin{abstract}
Irrigation is responsible for approximately $70 \%$ of the world's freshwater consumption and is one of the key factors behind the growing global water scarcity. Irrigation systems and techniques are extremely differentiated and complex. In this context, tools of computational fluid dynamics (CFD) earn relevance, allowing a detailed analysis and forecast of hydraulic behavior in different situations. In order to evaluate flow details in a dripper, this study applies CFD tools to study a drip irrigation system from three different perspectives: (i) analysis of the complete system of piping and dripper; (ii) analysis of only the isolated dripper expanded and biphasic model; and (iii) analysis of the isolated dripper operating in transient regime. Modeling results allowed a full understanding about speed fields, pressure and friction loss along the geometry. The drop formation process in the dripper output could be displayed in detail, and the obtained dripper flow output was close to the nominal value of manufacturer, in the case of the isolated dripper analysis. Although a comparison with results from experiments was not possible at the time, based on manufacturers' catalogs, results proved satisfactory, leading to successful simulations.
\end{abstract}

Keywords: computational fluid dynamics (CFD), dripper, irrigation.

\section{Modelagem e avaliação de desempenho hidráulico de dispositivo gotejador acoplado a rede de distribuição de água ramificada}

\section{RESUMO}

A irrigação é responsável por aproximadamente $70 \%$ do consumo de água doce do mundo e é um dos principais fatores por trás da crescente escassez de água global. As técnicas e sistemas de irrigação são extremamente diferenciadas e complexas. Neste contexto, as 
ferramentas de dinâmica de fluidos computacional (CFD) ganham relevância, permitindo uma análise detalhada e previsão do comportamento hidráulico em diferentes situações. Com o objetivo de avaliar os detalhes do escoamento no gotejador, o presente estudo se aplica a ferramentas de CFD para um sistema de irrigação por gotejamento sob três perspectivas diferentes: (i) analisando o sistema completo composto de tubulações e gotejador; (ii) analisar apenas o gotejador isolado expandido e modelo bifásico; e (iii) com o gotejador isolado operando em regime transiente. Os resultados da modelagem e simulação mais tarde permitiu uma visão completa dos campos de velocidade e pressão e fricção perda ao longo da geometria. O processo de formação de gotas na saída do gotejador pode ser exibido com detalhes e a saída do fluxo de gotejador obtido foi próximo ao valor nominal do fabricante, no caso de análises do gotejador isolado. Embora não tenha sido possível no momento uma comparação com resultados provenientes de experimentos, com base em catálogos de fabricantes, as qualidades dos resultados foram bons e modelagem bem sucedida.

Palavras-chave: dinâmica de fluidos computacional (CFD), gotejador, irrigação.

\section{INTRODUCTION}

As previously noted, irrigation systems and techniques are extremely differentiated and complex. Among these techniques is micro-irrigation or localized irrigation (Tang et al., 2017), which involves the application of water droplets slowly to the soil layers, the drip or microsprinkler technique.

Lamm et al. (2007) defines water system application, which consists of transmitters connected to a water supply from a low-pressure line. Li et al. (2018) notes that micro-irrigation not only increases the system's efficiency, but can also increase crop productivity. There are indications that drip systems, such as subsurface drip, may perform better, which may eventually expand the irrigation system's economic feasibility (Jacques et al., 2018), and enable its use along with deficit irrigation. (Al-Ghobari and Dewidar, 2018).

Quingsong et al. (2008) explains that, in localized irrigation systems, there are several types of drippers. Multiple geometric shapes can be used, but usually the device has very small dimensions and water flow passes through micro-holes as a satellite maze, making the pressure drop. The discharge rate is usually 1 to $8 \mathrm{l} / \mathrm{h}$ and is linked to the small width and flow path depth, which is about 0.5 to $1.5 \mathrm{~mm}$ in height (Patil et al., 2013). For low discharge rates and high uniformity in irrigated areas, many emitters adopt the hydraulic system of the path through the maze with a very low section of flow (usually less than $1 \mathrm{~mm}^{2}$ ).

Dripper installation can happen in two ways: (i) Drippers are attached to the polyethylene tube after drilling, which eases positioning of the transmitters under the plant tops; and (ii) Drippers are placed in polyethylene tubes, which permits formation of a wet range in the application area (Gomes, 1994). In drip systems, the liquid (usually water) is released by emitters with a very low power, so that the water flows very slowly into the soil (Palau-Salvador et al., 2004). According to Gomes (1994), the hydraulic behavior of drippers is characterized in a general way, using Equation 1.

$q=C_{d} \cdot h^{x}$

Where: $\mathrm{q}=$ dripper flow; $\mathrm{Cd}=$ proportionality coefficient, which depends on the dripper, cross section size and shape $\mathrm{h}=$ dripper service pressure; and $\mathrm{x}=$ discharge exponent dripper, which is a water flow function of emitter. The lower the " $x$ " exponent value, the less will be the flow variation before the pressure variation at the dripper inlet. If water flow through the dripper is made in the laminar regime, $\mathrm{x}$ is equal to 1 and the dripper flow varies linearly with

Rev. Ambient. Água vol. 14 n. 3, e2340 - Taubaté 2019 
pressure. For drippers which operate in turbulent regimes, $\mathrm{x}$ is approaching 0.5 , meaning that the issuer flow is less sensitive to a pressure variation ( $\mathrm{q}$ varies with the square root of $\mathrm{h}$ ) (Gomes, 1994).

Drippers are little sensitive to low pressure variation $(\mathrm{x})$, temperature variation and wear over time. These drippers are obviously more expensive, which may impact the total cost of irrigation system installation (Zanca, 2013).

There are several experimental scientific studies on drippers, especially in the agronomy field; however, mathematical modeling of drippers is infrequent.

For a better understanding and optimization of hydraulic components for irrigation systems, some authors (Tang et al., 2017; Bravo-Mosquera et al., 2018) have applied computational fluid dynamics tools (CFD), which allow detailed analysis of the fluid flow behavior to integrate the knowledge, fluid, mathematics and computing to solve flow equations, given by physical conservation laws and mathematical descriptions, such as the conservation of mass, Newton's second law and the first law of thermodynamics (Tu et al., 2013). Computational simulation technologies are an effective way of studying a fluid behavior, since they allow results to be analyzed punctually, permitting correlation and improvement projects, even before the construction of prototypes.

Dripper characteristics of the water must be fully understood so that they can be developed with low rates of clogging in the issuers. Obtaining a complete view of field, speed, pressure and other parameters involved with drippers then becomes extremely important for designers of drippers (Wu et al., 2013). In these terms, several authors (such as Wei et al., 2006; Li et al., 2008; Celik et al., 2015; among others) have researched dripper flows by means of CFD tools.

Wei et al. (2006) evaluated drippers flow of different geometries using computational hydrodynamics simulation software, obtaining ratios between hydraulic quantities in dripper canals, such as discharge, pressure and flow coefficients. Li et al. (2008) tried to optimize the geometry of a dripper maze, suggesting improvements to the flow along the dripper, demonstrating a greater capacity for self-cleaning.

The authors also compared the results obtained through CFD with a speedometer for bidimensional digital tracking of particles, achieving results very close in both approaches. $\mathrm{Wu}$ et al. (2013) studied the dripper flows, comparing different turbulence models k- $\varepsilon$ and the largesimulation and LES methods, and were able to explain the energy dissipation mechanism by speed and average pressure values of local regions for the entire course of its elimination.

In an analysis with a different focus, Celik et al. (2015) studied the loss of load in the piping of a drip irrigation system using 5 different CFD techniques, because they are not normally provided by the manufacturers of transmitters and are projected by estimated means and mathematical models (Gomes et al., 2010), demonstrating that the CFD techniques can be used not only for dripper optimization, but also to assist in system sizing, corroborating authors such as Baiamonte (2018) which studied design optimization for each side of the drip system.

In these terms, this work proposes a mathematical modeling of this hydraulic problem (less studied in this focus) and evaluates flow through drippers from three perspectives: (i) analysis of the complete system consisting of piping and dripper; ii) analysis of only the isolated dripper and with expanded output; and (iii) analysis of the dripper operating in transient regime. The second and third perspectives aim to better visualize the formation mechanism of drops; specific papers with this approach were not found in literature.

\section{MATERIAL AND METHODS}

This study divides CFD tool application into 4 steps: i) specification of the problem and its geometry; ii) discretization meshes and numerical method; iii) selection of boundary conditions and (iv) evaluation of results and interpretation (Lomax et al., 1999; Tu et al., 2013). 
The study approaches the removal of computational simulation in a dripper from three perspectives: the analysis of dripper piping system, analysis of the isolated dripper with expanded output and biphasic model, and an analysis of a similar case to the previous one, considering the transitional regime.

Dripper geometry specifications were obtained from a commercially manufactured model available in the Brazilian market, reproducing all of its geometric characteristics. The dripper has a maze format and the inserted piping has a diameter of $14 \mathrm{~mm}$. Built geometry has replicated the maze format and its different surfaces (inputs, outputs and walls) were defined. The mesh was created in accordance with the principle that regions that have more pronounced speed changes should be more thoroughly studied, to provide greater accuracy in baseflow changes, since in these regions the behavior of pressure ranges, speed profiles, among others should be studied.

The following contour conditions were introduced: flow rate of $0.3061 / \mathrm{s}$ along the piping and the outlet dripper pressure equal to atmospheric pressure (0). The turbulence model was the k- $\varepsilon$ (approved by Wei et al., 2006) and simulations were performed in permanent regime, since any condition of flow at the dripper output was introduced aiming to compare the result with manufacturer's model, which provided a nominal flow of $4 \mathrm{l} / \mathrm{h}$. The residue was used to ensure that the convergence that could be reached was 10-4 (as Aguirre et al., 2019) and the number of iterations required for convergence of dripper piping system was equal to 100 .

There is a very large-scale difference, showing that the dripper water outlet is affected. Thus, for better visualization purposes, in the following work we performed the second perspective simulation, with the same boundary-value conditions of the first event. This new simulation was performed with the dripper operating alone, excluding the piping. In addition, we expanded the dripper output drop-formation process to obtain better visualization (Figure 1). Thus, boundary conditions were applied directly to the exit of the dripper itself.

Biphasic modeling of dripper was performed with isolated simulations, aiming to improve the visualization of the drop-formation mechanism. We modeled the dripper output as an opening to allow contact between water and air, with a surface tension coefficient between fluids of $0.0722 \mathrm{~N} / \mathrm{m}$ (default value for air and water to $25^{\circ} \mathrm{C}$ ). We defined 400 as a maximum number of iterations for this scenario.

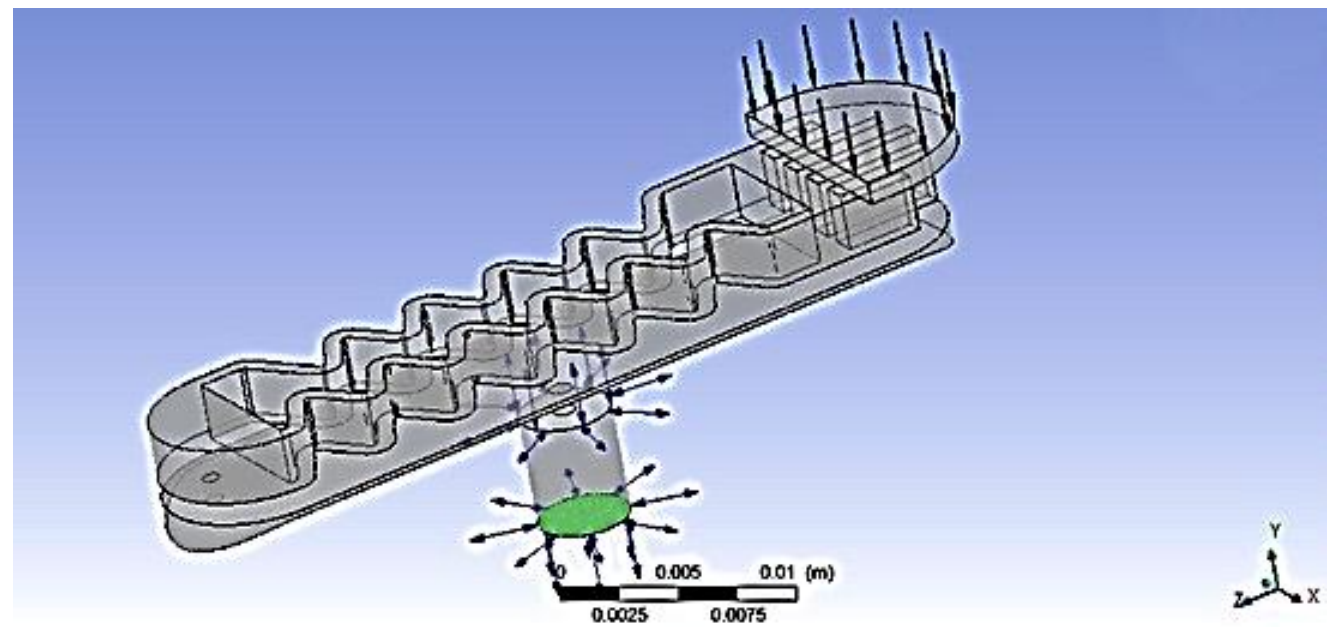

Figure 1. Analysis of geometry is defined for the scenario of insulated dripper with expanded output.

The third and last case was comparable to the second scenario, but in a transient regime, maintaining all other conditions. The total duration period adopted was 200 seconds, with increments of 1 second and 10 iterations for each second. In this scenario, the path along the 
dripper and the drops formation process could be visualized in an even more complete way than in other situations.

\subsection{Generation of meshes}

The mesh generated in the present study was simulation of non-structured mesh and hybrids with respect to the elements' types. Generated elements among the total number of geometry elements were 4,375,853.

\section{RESULTS}

\subsection{Results of simulation of the dripper piping system}

\subsubsection{Speed of fields analysis}

Figure 2 illustrates the current lines along Plane 1, as if the dripper were an obstacle. Current lines were imperceptible within the dripper, although some still indicate that there is water entering the dripper. A small increase in speed of flow along the piping can still be noticed. This is accomplished by reducing the flow area, by the fact that an "obstacle" has been introduced in the center of the tubing.

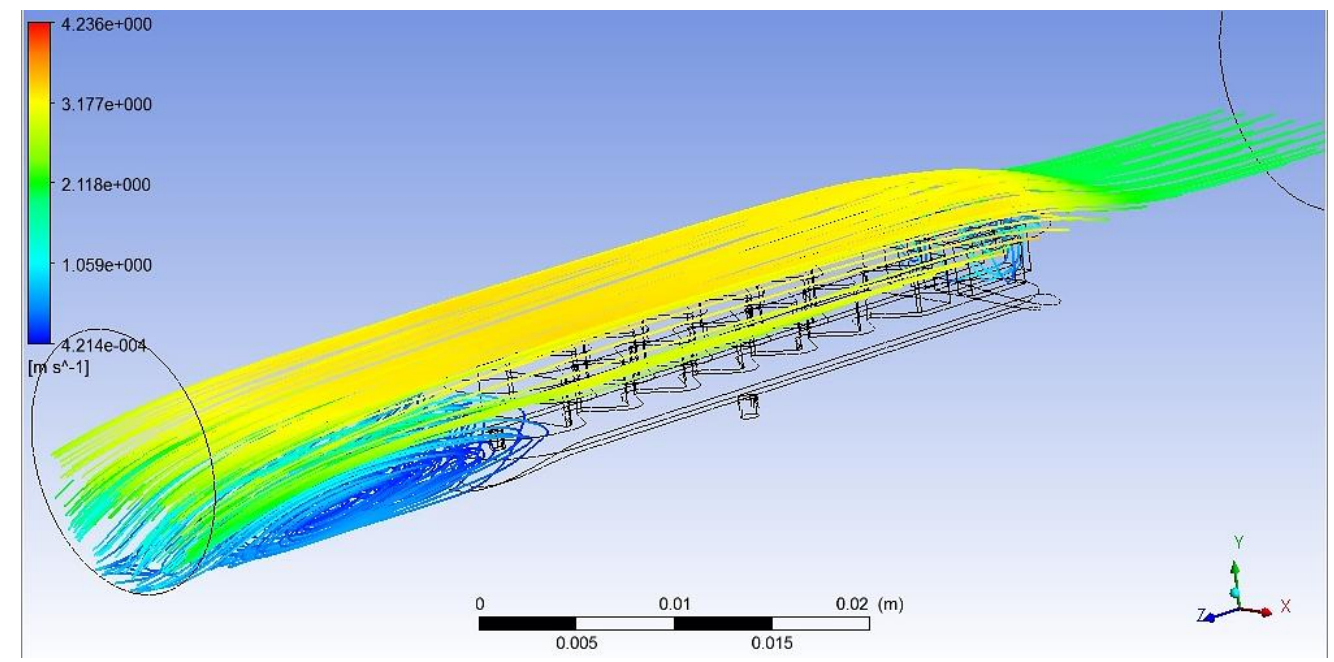

Figure 2. Current lines of the speed gradient on Plane 1.

Similarly, as the current lines of speed on Plane 1, the vectors of speed on the same plane are only inserted at the entrance of the dripper (Figure 3). In addition to the formation of vortices in the entrance of the dripper, they were also observed in speed vectors representing the mentioned shoulder (yellow).

In the YZ plane 2 (direction), the same procedures were entered for viewing the flow (observed in Figure 4).

The Figure 5 shows the speed-vector results.

Figure 6 shows the speed vectors with emphasis on the dripper, visualizing two openings. The left represents the waterflow from the hydraulic path and pours into a reservoir (lower drippers), with higher speed values. The right represents the output vector DRIPPER to the ground. There is high turbulence and vortice formation at the flow dripper's lower reservoir (left side), which can be detrimental to the equipment, damaging it. Average speed in the dripper output is $2 \mathrm{~m} / \mathrm{s}$. As the output diameter is $1 \mathrm{~mm}$, it is possible to apply the continuity equation $(\mathrm{Q}=\mathrm{V} \cdot \mathrm{A}$ in this region, obtaining a flow rate of $5.6 \mathrm{~L} / \mathrm{h}$ close value standard deviation of $40 \%$ of nominal when compared to industrial dripper, $4 \mathrm{~L} / \mathrm{h}$ - see section 2 ), showing the simulation's effectiveness in the dripper region, enabling expansion. In subsequent topics, we present a more detailed analysis and the need for dripper elimination.

\section{IPABH}

Rev. Ambient. Água vol. 14 n. 3, e2340 - Taubaté 2019 


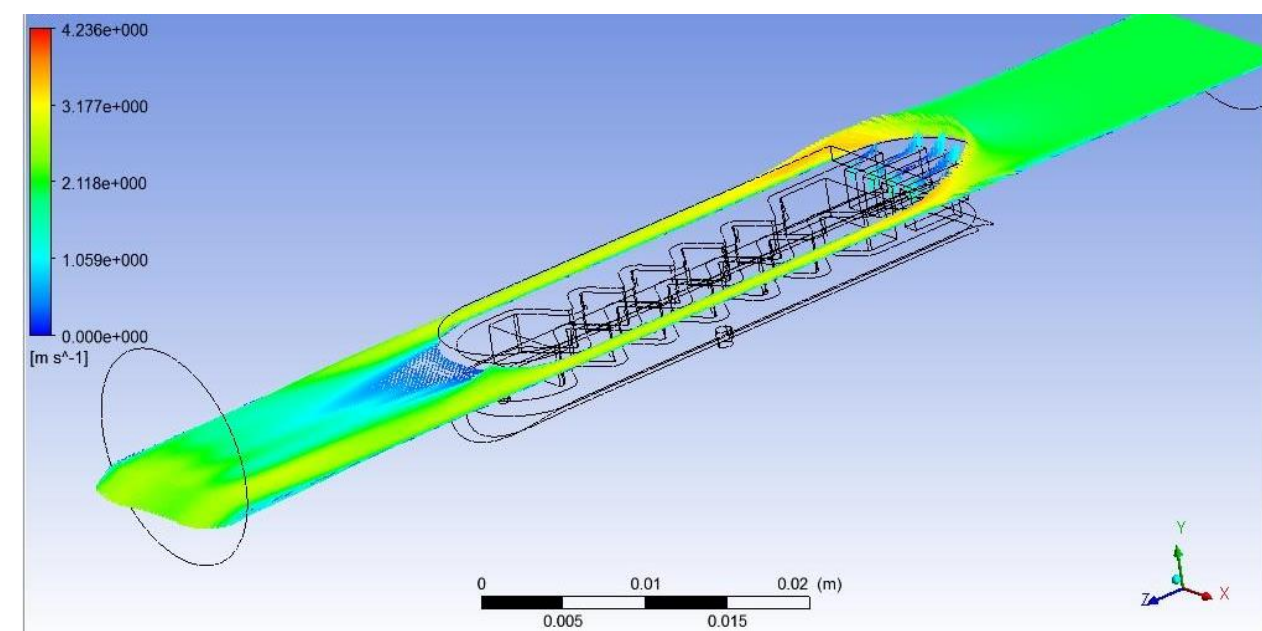

Figure 3. Speed vectors along Plane 1.

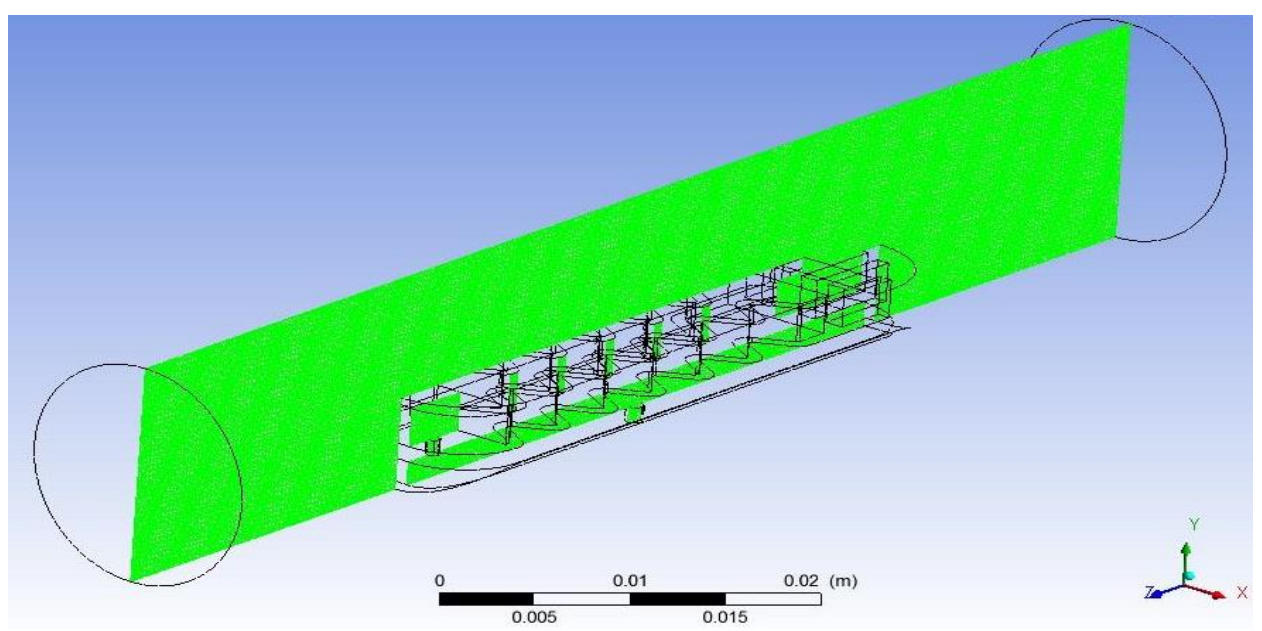

Figure 4. Speed vectors along the Plan 1.

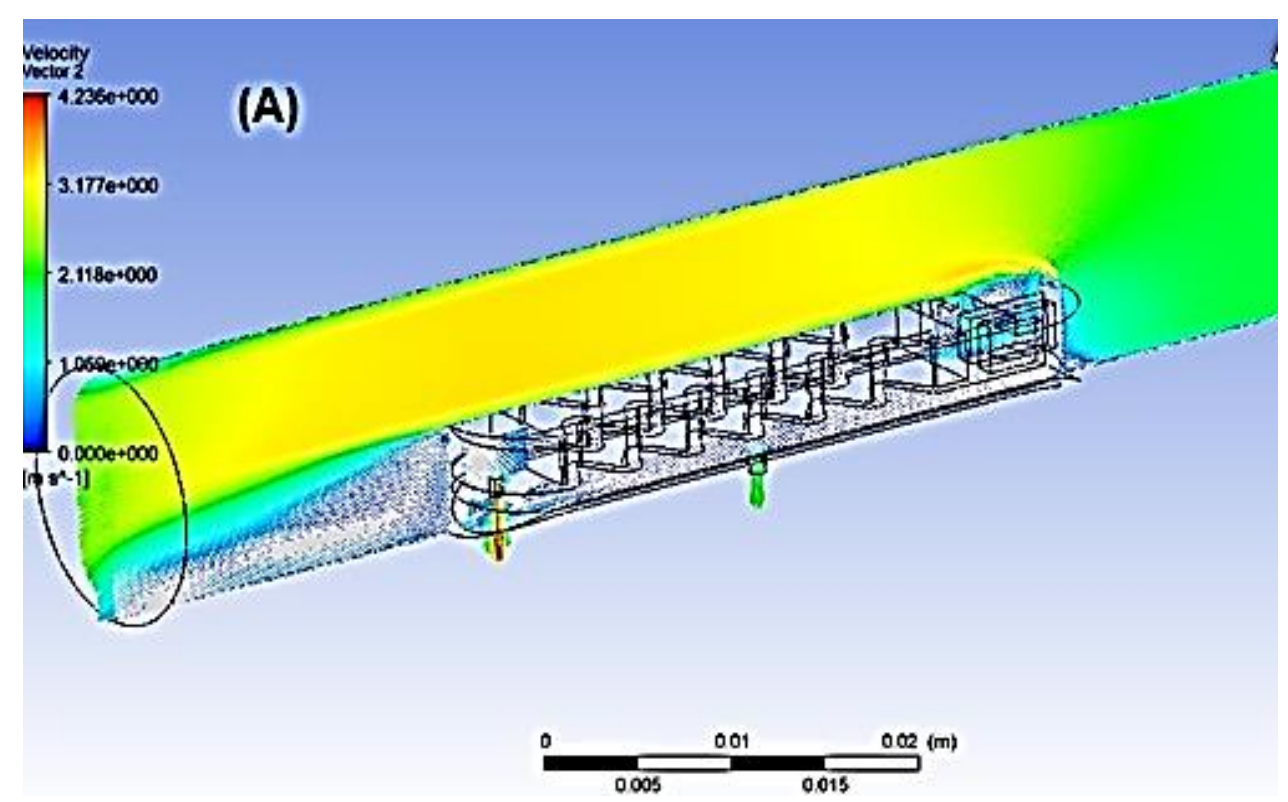

Figure 5. Dripper piping system transverse plane -. (A) analysis of speed; (b) analysis of pressure. 
Figure 6 shows the fields of dripper pipe at system pressure and a transverse plane. there is a slight increase in the flow speed along the piping.

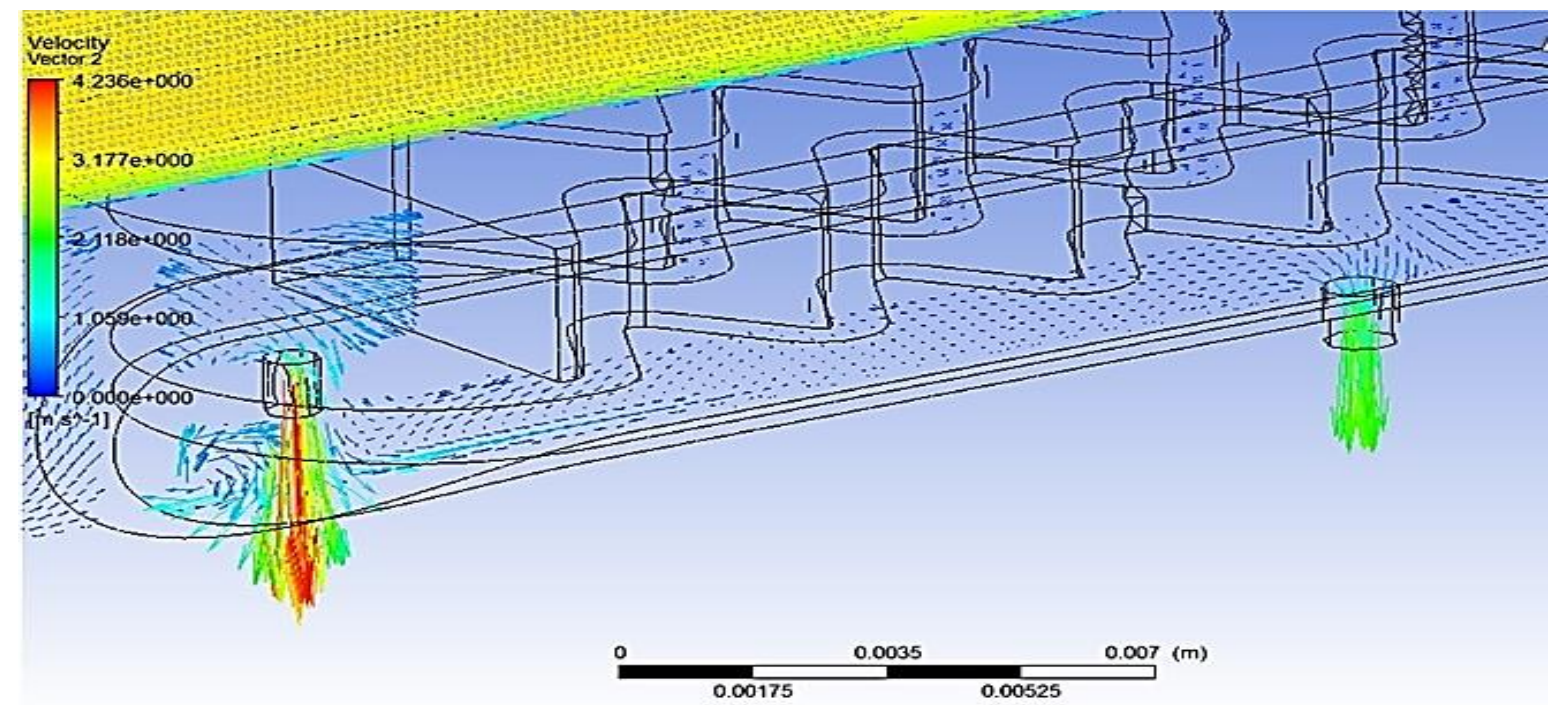

Figure 6. Speed vectors. Zoom of Dripper.

\subsubsection{Analysis of pressure fields}

The variation of the dripper's external pressure is very low (Figure 7). A pressure of approximately $2 \times 10^{4} \mathrm{~Pa}$ at the entrance of the dripper should be noticed. When the fluid reaches the region of the dripper, this Figure 7 drops to approximately $1.6 \times 10^{4} \mathrm{~Pa}$. This small variation of pressure noticed in contour region follows the speed variation. The speed increased as the pressure declined, confirmed by the Bernoulli equation for horizontal tubes. In this regard, the pressure increased by a value of $1.6 \times 10^{4} \mathrm{~Pa}$ at the dripper entrance.

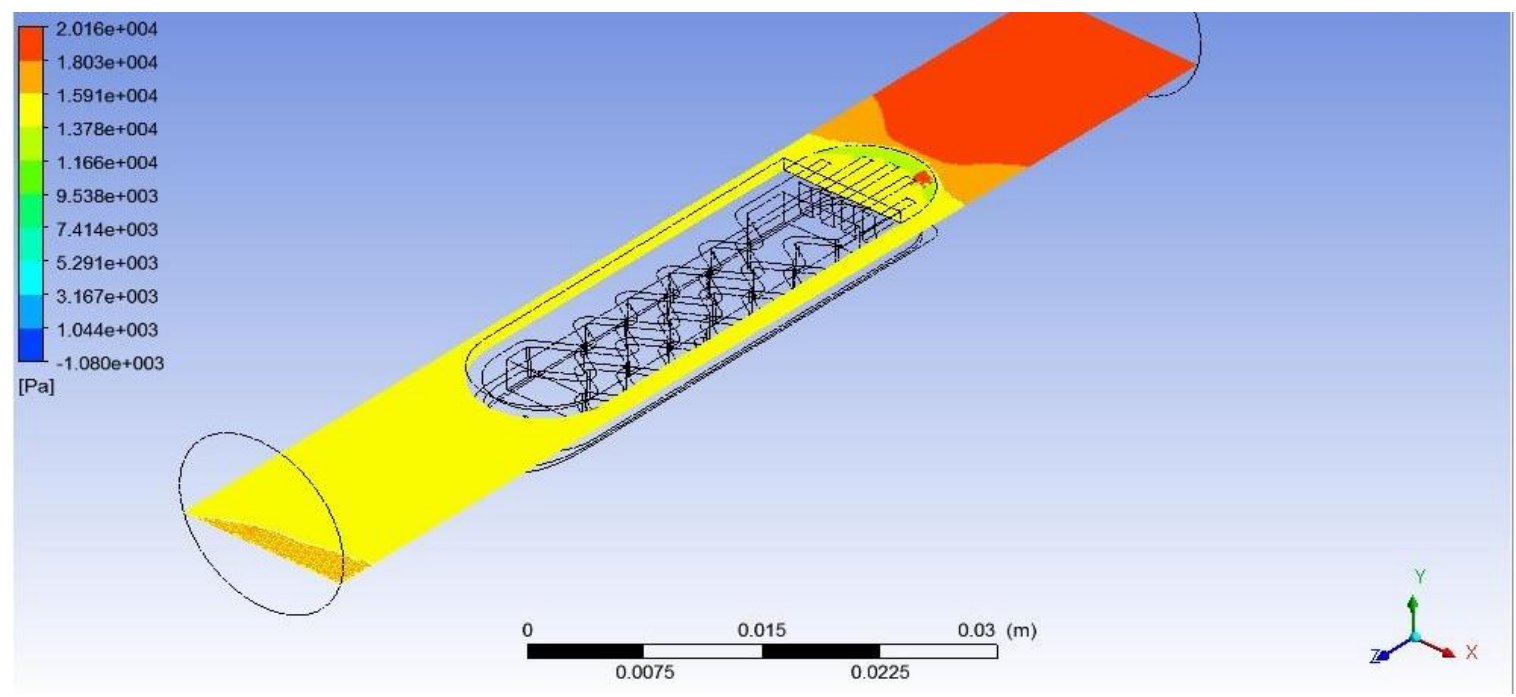

Figure 7. Current lines of the pressure gradient - Plane 1.

The pressure values presented within the dripper are very low (shown in Figure 8). This is caused because the loss of load caused by the hydraulic path is very high. The entry of the dripper (yellow) demonstrated the value of $1.6 \times 10^{4} \mathrm{~Pa}$, and already in the lower part of the dripper (blue) a decrease of pressure is clearly noticed. The value in light blue is approximately $4 \mathrm{kPa}$. 


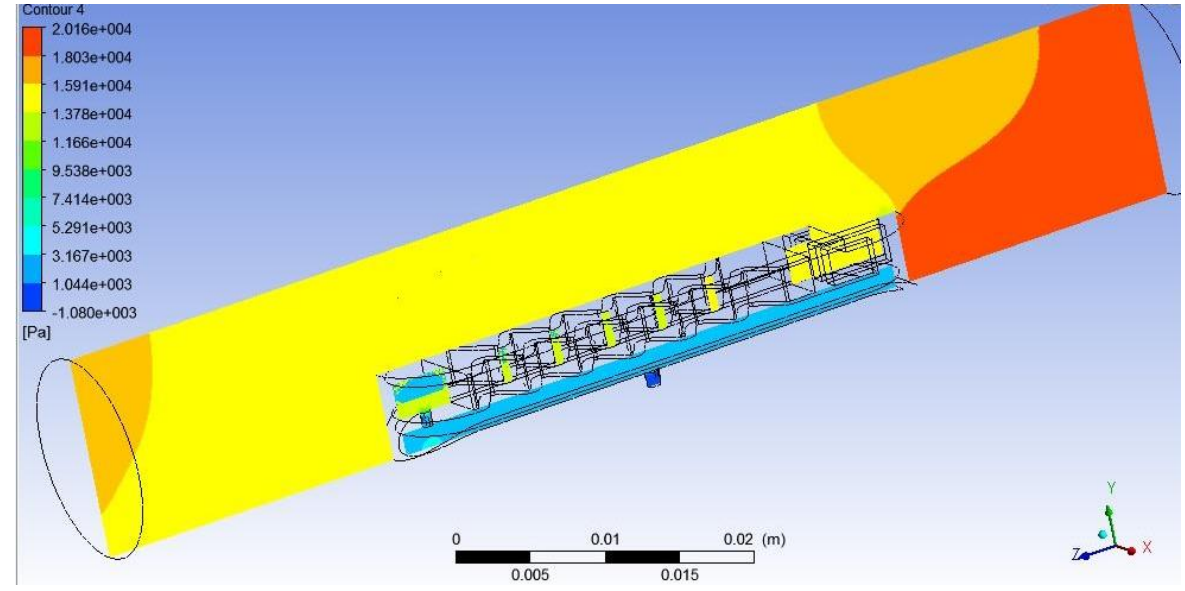

Figure 8. Current lines of the pressure gradient - Plane 2.

\subsubsection{Results of isolated dripper simulation with biphasic model}

In this case, we analyzed the dripper separately, with a biphasic model applied to the dripper with enlarged output to permit a more detailed view of the drop formation mechanism. Figure 9 shows the speed fields (9a) air and water volumetric fractions (9b) at the dripper output.

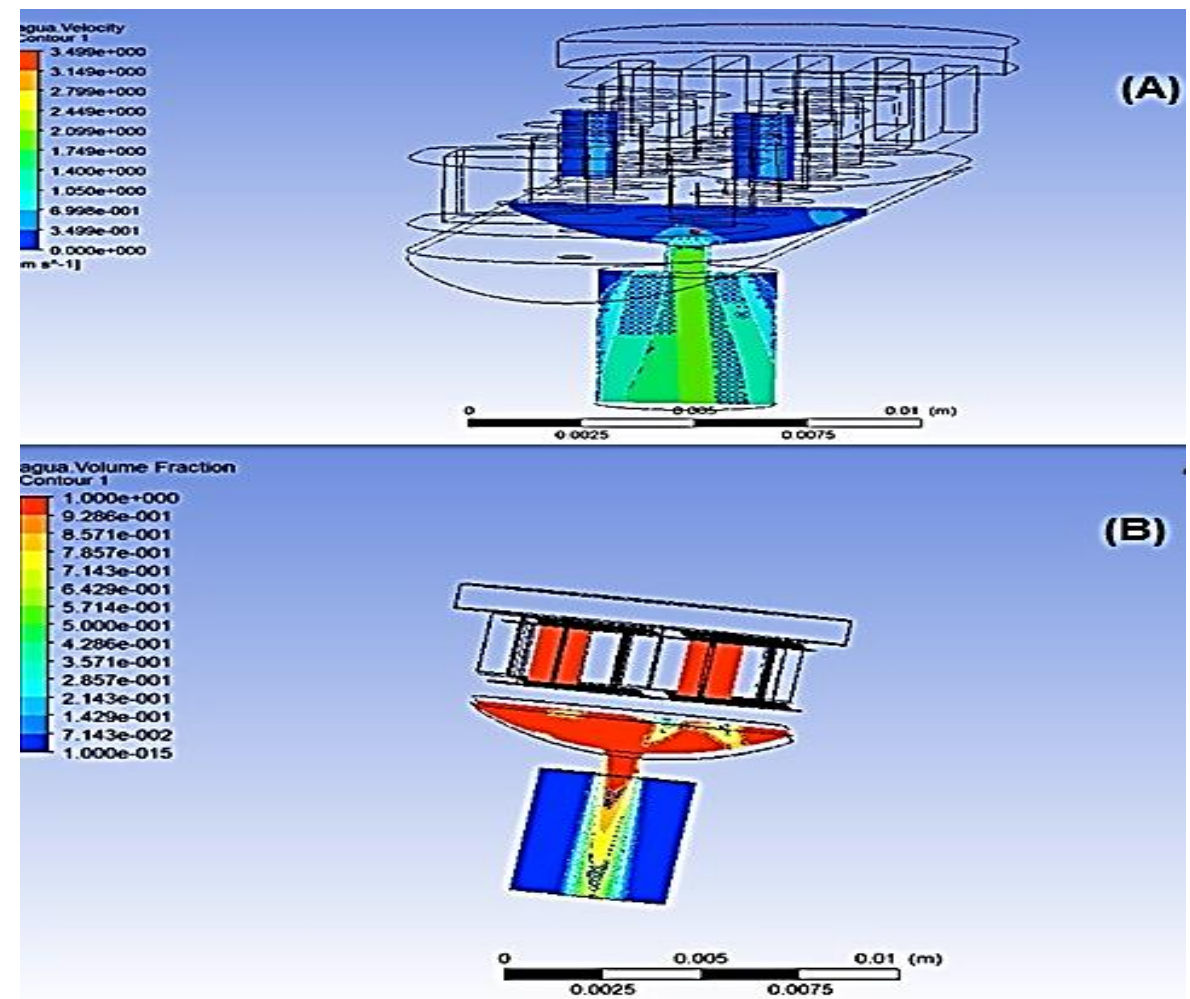

Figure 9. Insulated dripper with expanded output computational modeling. (A) speed fields; (b) air and water volumetric fractions.

As in the previous case, we can estimate that in the dripper output section velocity (Figure $9 \mathrm{a}$ - around $1.7 \mathrm{~m} / \mathrm{s}$ ) and the flow transmitter equal $4.8 \mathrm{~L} / \mathrm{h}$, which represents a deviation of $20 \%$ from the manufacturer's nominal value $(4 \mathrm{~L} / \mathrm{h})$, and indicates a good estimation, since it is a small structure and difficult to simulate computationally.

In Figure 9b, the model of drop formation process by volumetric fractions of air and water, where it seems that the concentration of water is more intense in the center of the dripper output pipe (region of higher speed in Figure 4), which indicates a fall is ocurring. There is still air in 
the lower part of the dripper body, which can avoid the drop-formation process and indicates a limitation of the geometry of the analyzed issuer.

\subsubsection{Simulation results of the isolated dripper with biphasic model and transitional provisions}

The simulation in transient regime was applied to show the drop-formation dynamics over time. Figure 10 illustrates the temporal evolution of the volumetric fraction of water in the dripper (taken from an animation) and allows the visualization of the drop formation process on the emitter from the beginning of drop formation until the complete dissipation of its heat. In the upper part of the drop formation, the intrusion of air in the dripper is observed, while the water flows from the lower part of the reservoir to the main output. At the dripper output, we observed bulb formation in different volumetric water fractions, indicating the non-uniformity of water volume along the fall. In the last frames of Figure 10, we detected very small water volumes, indicating the end of a water portion in the dripper, after the drop formation. At the end of the developed process, the dark blue color indicates a value of about $0 \%$, caused by fall that reaches the soil.

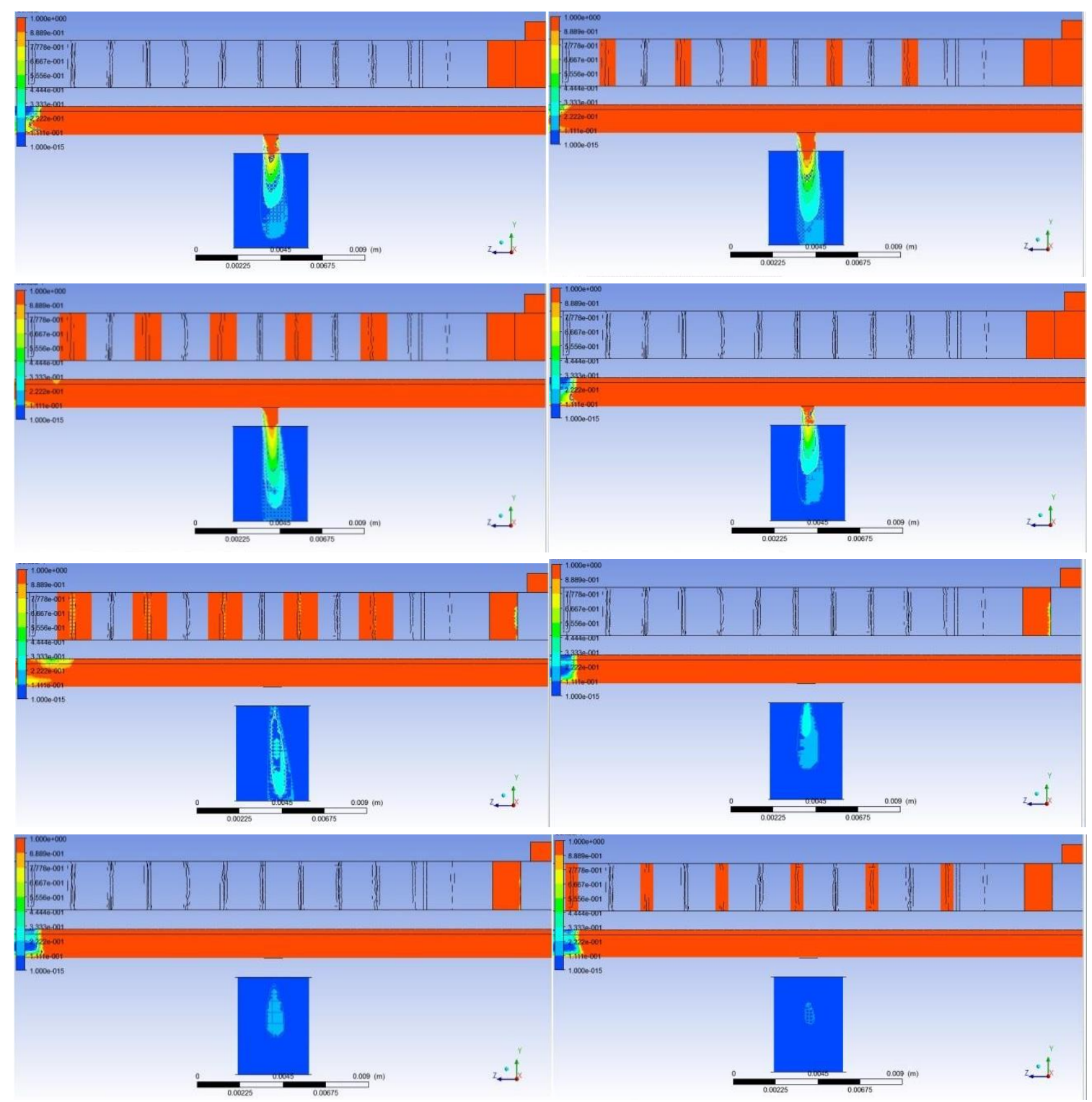

Figure 10. Temporal evolution of the volumetric fraction of water during the process of drop formation and emission. 


\section{CONCLUSIONS}

Results permitted a full detailed view of the dripper types inline. Field studies of flowpressure simulation along the tube dripper system enabled the load loss calculation imposed by the flow in dripper tube (close to $4 \mathrm{kPa}$ ). This demonstrates that the complete system of simulations, as achieved in this study, may be used to help in optimizing these structures' geometry, minimizing energy losses.

Additional simulations, focused on the dripper isolated with biphasic model and, later, with a transient regime, allowed a more detailed view within the dripper and verification of dropformation mechanism concomitantly. The behavior of the output dripper (dripper isolated at flow output) was very close when compared to results of manufacturer. Deviations presented were $20 \%$, considered a satisfactory value, since it is a difficult study in computational geometry.

In the simulation of transient regime, we checked the drop formation process from details until its complete heat dissipation in the dripper output. Strong air intrusion appeared, especially at the beginning of drop formation, which may indicate a geometric limitation. The drop formation mechanism would be perceived more clearly if new surface-value adaptations of water tension were adopted and/or if the number of steps for the simulation results analysis were increased. Such analyses are suggestions for future work.

Similar analyses performed in this study could be compared with laboratory analyses to optimize the dripper results, assisting a more efficient design, requiring less material and/or providing a greater speed in the drop formation mechanism, which makes the computational fluid dynamics techniques of great relevance to achieve greater efficiency in irrigation projects.

In addition, some perturbation was introduced to evaluate the sensitivity of responses; however, these studies can be presented as the continuity of work.

\section{ACKNOWLEDGMENTS}

The authors thank finep Redecope Project - MCT (Ref. 0983/10) - Ministry of Science and Technology entitled "Development of efficient technologies for hydro management efficiency in water supply systems" program and the researcher Miner Fapemig for the PPM - 00755-16 besides thanking NUMMARH- Nucleos modeling in simulation in Environment and Water Resources and systems of unified. Thanks to CAPES for the master's scholarship of the author 4. "Thanks CAPES, for the master's scolarship number 1764063 to the author Alex Takeo Yasumura Lima Silva".

\section{REFERENCES}

AL-GHOBARI, H. M.; DEWIDAR, A. Z. Integrating the deficit irrigation in surface and subsurface drip, as a strategy to save water in arid regions. Agricultural Water Management, v. 209, p. 55-61, 2018. https://doi.org/10.1016/j.agwat.2018.07.010

AGUIRRE, A. C.; CAMACHO, A.; OLIVEIRA, W.; AVELLAN, F. Numerical Analysis to detect loss of head on trifurcations of high head in hydropower. Renewables, v. 131, p. 197-207, 2019. https://doi.org/10.1016/j.renene.2018.07.021

BAIAMONTE, G. Advances in designing drip irrigation laterals. Agricultural Water Management, v. 199, p. 157-174, 2018. https://doi.org/10.1016/j.agwat.2017.12.015

Rev. Ambient. Água vol. 14 n. 3, e2340 - Taubaté 2019 
BRAVO-MOSQUERA， P. D.; CERÓN-MUÑOZ， H. D.; DÍAZ-VÁZQUEZ， G.; CATALANO, F. M. Conceptual design and CFD analysis of the new prototype of agricultural aircraft. Aerospace Science and Technology, v. 80, p. 156-176, 2018. https://doi.org/10.1016/j.ast.2018.07.014

CELIK, H. K.; KARAYEL, D.; LUPEANU, M. E. et al. Determination of head loss in parts of drip irrigation system with emitters of cylindrical type online through the CFD analysis. Bulgarian Journal of Agricultural Science, v. 21, p. 703-710, 2015.

GOMES, A. W. A.; FRIZZONE, J. A.; RETTORE NETO, O.; MIRANDA, J. H. Local head losses for integrated drippers in polyethylene pipes. Agricultural Engineering, v. 30, n. 3, p. 435-446, 2010. http://dx.doi.org/10.1590/S0100-69162010000300008

GOMES, H. P. Engineering of irrigation. Recife: UFPE, 1994.

JACQUES, D.; FOX, G.; WHITE, P. Farm level economic analysis of subsurface drip irrigation in Ontario corn production. Agricultural Water Management, v. 203, p. 333-343, 2018. https://dx.doilorg/10.1016/j.agwat.2018.03.018

LAMM, F. R.; AYARS, J. E.; NAKAYAMA, F. S. (Eds.). Microirrigation for crop production: design, operation and management. Oxford: Elsevier, 2007.

LI, Y.; YANG, P.; XU, T.; REN, S.; LIN, X.; WEI, R.; XU, H. CFD and digital particle tracking to assess flow characteristics in the labyrinth flow path of a drip irrigation emitter. Irrigation Science, v. 26, p. 427-438, 2008. https://doi.org/10.1007/s00271-008-0108-1

LI, J.; XU, X.; LIN, G. et al. Micro-irrigation improves grain yield and resource use efficiency by co-locating the roots and $\mathrm{N}$-fertilizer distribution of winter wheat in the North China Plain. Science of the total environment, v. 643, p. 367-377, 2018. https://doi.org/10.1016/j.scitotenv.2018.06.157

LOMAX, H.; PULLIAM T. H.; ZINGG, D. W. Fundamentals of computional fluid dynamics. Dynamics Computing, University of Toronto: Institute for Studies of Aerospaces. Nasa Ames Research, 1999, 334p. https://dx.doi.org/10.1007/978-3-66204654-8

PALAU-SALVADOR, G.; ARVIZA-VALVERDE, J.; BRALTS, V. F. Hydraulic flow behaviour through an in-line Emitter Labyrinth using CFD techniques. St. Joseph: ASABE, 2004. https://dx.doi.org/10.13031/2013.16437

PATIL, S. S.; NIMBALKAR, P. T.; JOSHI, A. Hydraulic study, design and analysis of different geometries of drip irrigation emitter labyrinth. International Journal of Engineering and Technology IJEAT, v. 2, p. 455-462, 2013.

QUINGSONG, W.; GANG, L.; JIE, L. et al. Evaluations of emitter clogging in drip irrigation by two-phase flow simulations and laboratory experiments. Computers and Electronics in Agriculture, v. 63, p. 294-303, 2008. https://doi.org/10.1016/j.compag.2008.03.008

TANG, P.; LI, H.; ISSAKA, Z.; CHEN, C. Impact forces on the drive spoon of a large cannon irrigation sprinkler: Simple theory, CFD numerical simulation and validatio. Biosystem Engineering, v. 159, p.1-9, 2017. https://doi.org/10.1016/j.biosystemseng.2017.04.005

TU, J.; YEOH, G. H. LIU, C. Computational Fluid Dynamics: a practical approach. $2^{\text {nd }}$ ed. New York: Elsevier, 2013. 439 p. 
WEI, Q.; SHI, Y.; DONG, W.; LU, G.; HUANG, S. Study on the hydraulic performance drip emitters of computational fluid dynamics. Agricultural Water Management, v. 84, v. 1-2, p. 130-136, 2006. https://doi.org/10.1016/j.agwat.2006.01.016

WU, D.; LI, Y-K.; LIU, H-S. et al. Simulation of the flow characteristics of a drip irrigation emitter with large eddy methods. Mathematical and computational modeling, v. 58, p. 497-506, 2013. https://doi.org/10.1016/j.mcm.2011.10.074

ZANCA, R. B. Modelagem e simulação computacional de um sistema de irrigação por gotejamento. 2012. Trabalho de Conclusão de curso (Graduação em Engenharia Hídrica) - Universidade Federal de Itajubá, Itajubá, 2013. 